\title{
Резистентність до протимікробних препаратів: світові виклики та проблемні питання пандемії COVID-19
}

\author{
А.Р. Хиць \\ Редакція журналу «Український медичний часопис»
}

26 березня 2021 р. у цифровому форматі відбувся I Національний медичний конгрес з міжнародною участю «Протимікробна резистентність. Світові виклики». Програма заходу включала обговорення найгострішої теми сьогодення, а саме: резистентності до протимікробних препаратів, оскільки стрімке зростання поширеності цієї проблеми $\epsilon$ глобальним викликом для медицини, що потребує застосування невідкладних заходів. Організатором заходу виступило Всеукраїнське лікарське товариство, співорганізаторами ТОВ «Моріон» та ТОВ «УкрКомЕкспо».

\section{Резистентність до протимікробних препаратів як глобальна проблема}

Відкриваючи конгрес, із вступним словом до присутніх звернувся президент Всеукраїнського лікарського товариства Олег Мусій. Він привітав учасників та висловив слова подяки співорганізаторам конгресу, після чого перейшов до першої доповіді симпозіуму «Національний план заходів з протидії мікробній резистентності». Резистентність до протимікробних препаратів глобальна проблема людства, асоційована з неправильним та надмірним призначенням антибактеріальних лікарських засобів не за показаннями, що особливо актуально в умовах світової пандемії COVID-19. Ця проблема $\epsilon$ актуальною для всіх країн світу, боротьба з нею триває вже не одне десятиліття.

Ще у 2001 р. було опубліковано першу Глобальну стратегію Всесвітньої організації охорони здоров'я (ВОО3) щодо стримування резистентності до протимікробних препаратів (WHO Global Strategy for Containment of Antimicrobial Resistance), яка передбачала проведення комплексу заходів (консультативні групи, семінари експертів та консенсусні зустрічі), метою яких була боротьба з появою нових резистентних штамів і припинення поширення вже існуючих мікроорганізмів з резистентністю до протимікробних лікарських засобів [1]. У цій стратегії надано 68 пріоритетних рекомендацій щодо застосування протимікробних препаратів в медицині, вете- ринарії, агроіндустрії та зовнішньому середовищі. У травні 2015 р. 68-ма Всесвітня асамблея здоров'я ВООЗ прийняла глобальну резолюцію, яка стала підсумком 15-річної боротьби з резистентністю до протимікробних лікарських засобів, у якій схвалено глобальний план дій щодо боротьби з резистентністю до протимікробних препаратів, що спрямований на забезпечення профілактики та лікування інфекційних хвороб за допомогою безпечних та ефективних лікарських засобів [2]. Відповідно до цього було надано рекомендації щодо розробки і затвердження адаптованих національних планів дій з боротьби з резистентністю до протимікробних препаратів для кожної з країн світу на основі цієї резолюції, з наданням звіту про їх виконання кожні 2 роки. Як наслідок, такі світові організації, як BOO3, Продовольча та сільськогосподарська організація (Food and Agriculture Organization - FAO) та Всесвітня організація охорони здоров'я тварин (World Organization for Animal Health — WOAH) розробили спільний документ «Глобальні рамки для розвитку та управління боротьби з протимікробною резистентністю».

В Україні проблема резистентності до протимікробних препаратів набула значних масштабів, оскільки в нашій країні їй не приділяється достатня увага, а всі антибактеріальні лікарські засоби $\epsilon$ безрецептурними, що призводить до самолікування та безконтрольного застосування таких препаратів. Крім того, ще одна проблема нашої держави полягає у відсутності статистичних даних щодо поширення резистентності до протимікробних препаратів.
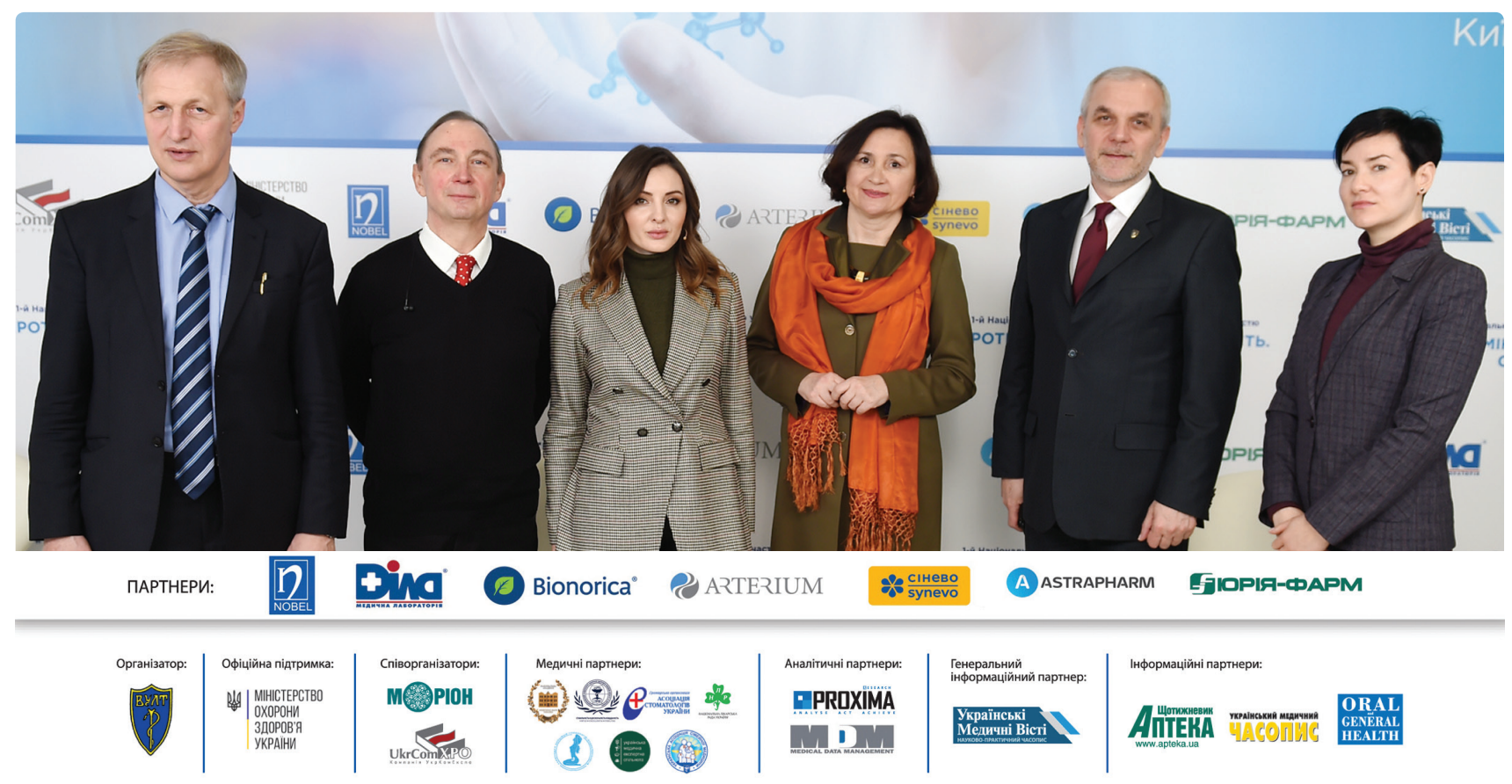
Рис. 1 Результати європейського опитування лікарів щодо резистентності до протимікробних препаратів (a); причини, з яких лікарі не інформують пацієнтів щодо резистентність до протимікробних препаратів (б)

(a) Результати європейського опитування лікарів щодо джерел, з яких вони отримують інформацію про антибіотикорезистентність

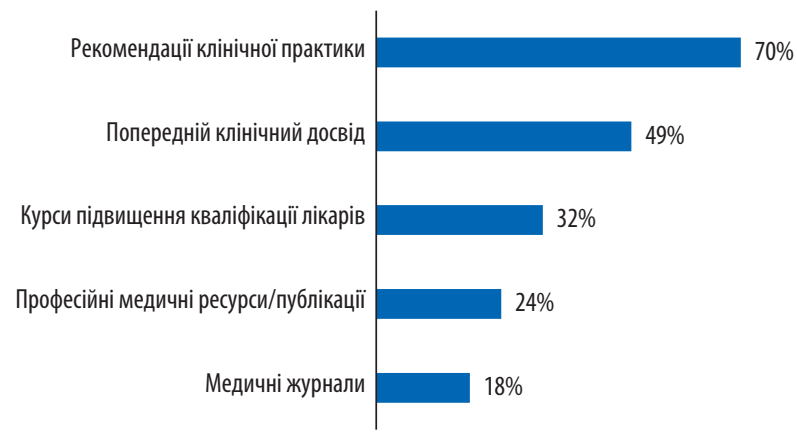

Так, востаннє Україна подала дані до Карти резистентності до антибіотиків (АБ) (ResistanceMap) щодо різних груп антибактеріальних препаратів за період 2010-2015 рр., відповідно, інформація за останні 6 років відсутня. Сучасні дані свідчать, що проблема неефективності АБ набуває загрозливих масштабів, що вимагає застосування цілеспрямованих заходів щодо боротьби з резистентністю до протимікробних препаратів.

Сьогодні різні громадські організації нашої країни беруть участь у боротьбі з резистентністю до протимікробних препаратів, проводять різноманітні заходи, спрямовані на інформування не лише медичних працівників, а й популяції в цілому. Так, упродовж останніх 3 років в рамках Всесвітнього тижня правильного застосування антибіотиків (2018-2020рр.) проведено 3 конгреси «Раціональне використання антибіотиків. Antibiotic resistance STOP!», які об'єднали фахівців України та світу з метою обговорення проблеми зниження ефективності АБ і пошуку нових підходів у боротьбі з резистентністю до протимікробних препаратів. На загальнодержавному рівні прийнято розпорядження Кабінету Міністрів України (КМУ) від 06.03.2019 p. № 116-р «Про затвердження Національного плану дій щодо боротьби із стійкістю до протимікробних препаратів», у якому визначені основні завдання для державних органів нашої країни щодо дій, спрямованих на боротьбу з резистентністю до протимікробних препаратів. На жаль, сьогодні імплементація плану не відбувається у передбаченому обсязі та у відповідні терміни і до цього часу українська влада не почала виконувати взяті на себе перед ВОО3 зобов'язання. Однак проблема резистентності до протимікробних лікарських засобів була і залишається актуальною в нашій державі, що потребує вжиття невідкладних заходів.

Підсумовуючи свою доповідь, О. Мусій зазначив, що в рамках 1-го Національного медичного конгресу з міжнародною участю «Протимікробна резистентність. Світові виклики» буде надіслано звернення до КМУ та Ради національної безпеки та оборони України щодо необхідності посилення в нашій державі заходів, спрямованих на боротьбу з резистентністю до протимікробних препаратів. Організаційним комітетом опрацьовано відповідний проєкт Резолюції Конгресу, який передбачає підтримку основних стратегічних цілей боротьби з резистентністю до протимікробних лікарських засобів, у тому числі контроль за виконанням розпорядження КМУ від 06.03.2019 р. № 116-р «Про затвердження Національного плану дій щодо боротьби із стійкістю до протимікробних препаратів».

Стратегічні цілі боротьби з резистентністю до протимікробних препаратів:

- покращити обізнаність та розуміння резистентності до протимікробних лікарських засобів;

- посилити знання за допомогою спостереження та досліджень;

- знизити частоту зараження;

- оптимізувати застосування протимікробних засобів;

- розробити економічні обгрунтування інвестицій, що враховують потреби всіх країн, та збільшити обсяг інвестицій в нові ліки, засоби діагностики, вакцини тощо. (б) Причини, з яких лікарі не інформують пацієнтів щодо антибіотикорезистентності

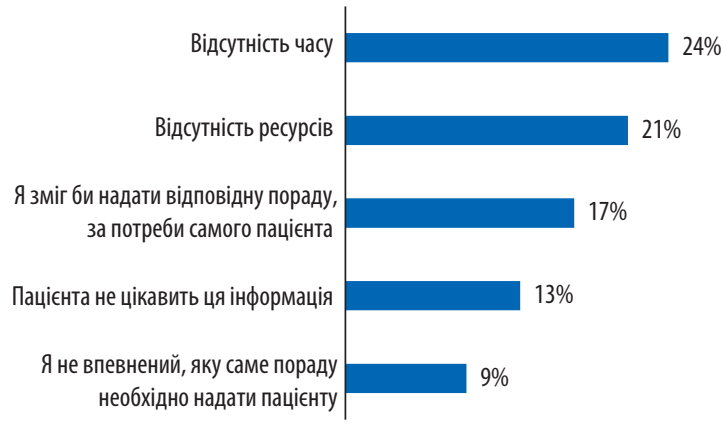

Аннабель Сібом, член Постійного комітету європейських лікарів (Standing Committee of European Doctors - CPME), та Пьотр Колчинський, член СРMЕ, у своїй доповіді представили звіт щодо результатів дослідження «Що європейські лікарі знають про антибіотики та стійкість до антибіотиків?». Для формування цього звіту робочою групою було проаналізовано результати опитування >7 тис. європейських лікарів щодо питань, які стосувалися резистентності до протимікробних препаратів, у тому числі стосовно того, чи ефективні АБ при вірусній етіології захворювання, ризиків, асоційованих із застосуванням АБ не за показаннями, оцінено рівень обізнаності лікарів щодо показань АБ та ін. Відповідно до отриманих результатів виявлено, що значна кількість $\epsilon$ Вропейських лікарів інформовані про проблему резистентності до протимікробних препаратів, яка в першу чергу асоційована з неправильним призначенням АБ, та дотримуються у своїй рутинній клінічній практиці міжнародних рекомендацій (рис. 1a).

Результати дослідження також продемонстрували, що лише $17 \%$ опитуваних лікарів розуміють важливість ролі інформування пацієнтів щодо ризиків, асоційованих з неналежним застосуванням АБ, та застосовують цю практику у своїй клінічній діяльності. До причин, з яких лікарі не приділяють цьому питанню значної уваги, належать: брак часу, відсутність ресурсів, відсутність бажання самого пацієнта та ін. (рис. 16). Ці результати свідчать про необхідність підняття питання раціональної антибіотикотерапії та проблеми резистентності до протимікробних препаратів на належний рівень, тобто необхідним $\epsilon$ створення відповідних ресурсів для систематичного інформування клініцистів та паці$\epsilon$ єтів про проблеми резистентності до протимікробних препаратів. Таким чином, створення національних планів щодо боротьби з резистентністю до протимікробних лікарських засобів $\epsilon$ ключовою стратегією боротьби з їі поширенням.

Наступним спікером стала Лана Лур'є, кандидат медичних наук, яка у своїй доповіді приділила увагу результатам українського дослідження «Що українські лікарі знають про антибіотики та антимікробну резистентність? Аналітика ринку та лікарських призначень», яке проводилося як онлайн-опитування лікарів терапевтичного ( $n=240$, сімейні лікарі, терапевти та педіатри) та хірургічного профілів ( $n=150$, хірурги) за анкетою Європейського центру з профілактики та контролю захворюваності (European Centre for Disease Prevention and Control - ECDC) 3 метою оцінки глибини знань та з'ясування ставлення медичних працівників до призначення АБ і розвитку резистентності до протимікробних препаратів, що особливо актуально в умовах пандемії COVID-19.

Результати українського дослідження:

- 88\% лікарів вважають, що існує потреба в жорсткому регулюванні клінічних протоколів щодо призначення антибіотикотерапії (рис. 2a);

- 59\% вважають, що вільне придбання АБ пацієнтами $\epsilon$ абсолютно неприпустимим (рис. 26);

- 64\% лікарів вважають, що єдиним дієвим механізмом протидії нераціональному застосуванню АБ $\epsilon$ державна реімбурсація АБ, які призначаються за клінічними протоколами (рис. 2в); 
Рис. 2 Ставлення лікарів до: $a$ - масової антибактеріальної терапії, 6 - вільного придбання АБ пацієнтом, в - державної реімбурсації певних АБ, які призначаються за клінічними протоколами та 2 - безконтрольного призначення АБ при багатьох станах, асоційованих із запальними процесами

(а) Ставлення лікарів до масової антибактеріальної терапії

Рятує життя багатьом хворим,

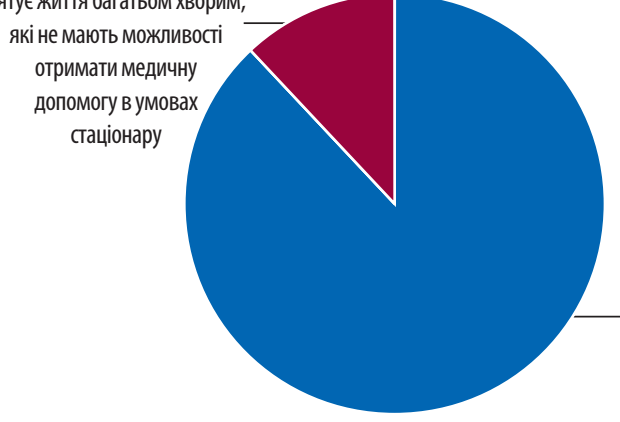

(в) Ставлення лікарів до державної реімбурсації певних АБ, які призначаються за клінічними протоколами

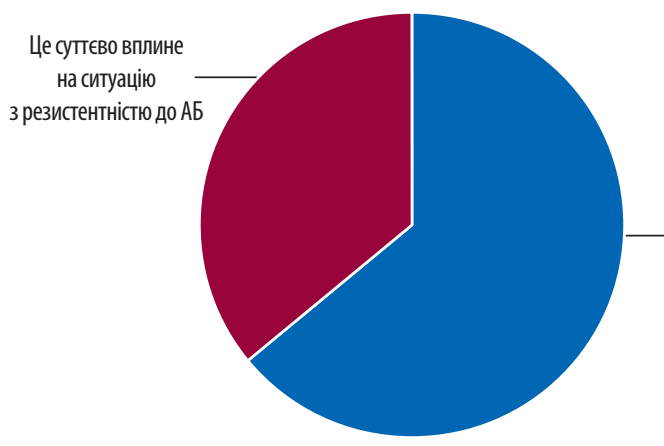

Це єдиний механізм - протидії нераціональному використанню АБ

\section{Відсутність обов'язкових стандартів лікування} і контроль над оборотом рецептів жує протоколами

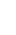

бажання лікаря відповідати очікуванням пацієнта очікуванням пацієнта
на швидке одужання

(б) Ставлення лікарів до вільного придбання АБ пацієнтом

(2) Ставлення лікарів до безконтрольного призначення АБ при багатьох станах, асоційованих із запальними процесами

$$
\text { асоційованих із запальними процесами }
$$

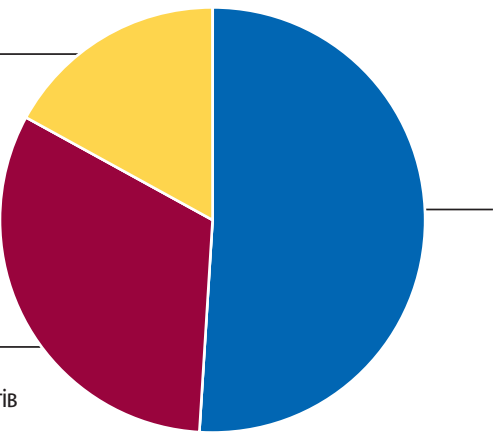

Результат необізнаності безлічі людей про наслідки нецільового призначення АБ

- 51\% лікарів вважають, що ключовою проблемою безконтрольного застосування АБ при багатьох станах, асоційованих із запальними процесами, $\epsilon$ саме необізнаність безлічі людей про наслідки нецільового призначення АБ (рис. 22).

Таким чином, отримані результати вказують на необхідність посилення в Україні заходів, спрямованих на боротьбу з резистентністю до протимікробних препаратів, зокрема підтримання основних стратегічних цілей ВООЗ та розробка та впровадження системи контролю за застосуванням АБ.

\section{Резистентність до протимікробних препаратів: механізми формування, клініка та діагностика}

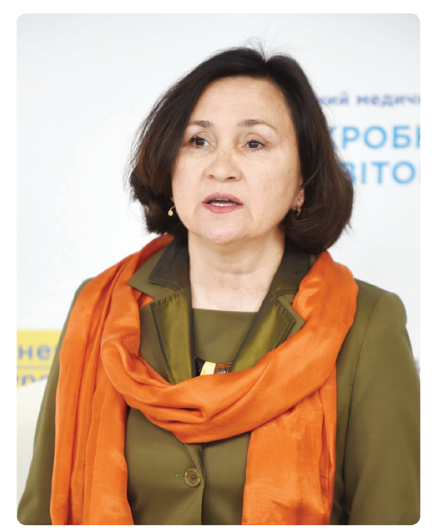

Друга частина конгресу розпочалася 3 доповіді доктора медичних наук, професора, президента громадської організації «Асоціація стоматологів України», представника України в СРМЕ Ірини Мазур, яка виступила 3 доповіддю «Мікробіом порожнини рота як джерело стійкості до антибіотиків». Спікер у своїй доповіді приділила значну увагу проблемі формування біофільмів/біоплівок у порожнині рота, які $є$ особливою формою організації мікрофлори в певному біотопі. Біофільм/біоплівка - складний, частіше мультивидовий, шар мікроорганізмів, що характеризується виділенням позаклітинної матриці, яка утримує мікроорганізми разом, виконує захисні функції і допомагає прикріплятися до поверхні [3].

Особливості життєдіяльності мікроорганізмів у біоплівці:

- генетична пластичність: швидка еволюція мікроорганізмів та модифікація генетичної інформації шляхом горизонтальної передачі генів;
- формування гарячих точок генетичної рекомбінації: значний вміст позаклітинної ДНК;

- високий рівень мутагенності:

- поява та розповсюдження генів резистентності до протимікробних препаратів та вірулентності;

- формування мультистійких «супербактерій» [4].

Тобто біофільм являє собою бактеріальну спільноту, яка прикріплена до органа/тканини організму, що має позаклітинний матрикс (ДНК, бактеріальні полісахариди та резистентні білки). При цьому ключова роль позаклітинної ДНК полягає в тому, що вона $\epsilon$ структурним компонентом матриксу біоплівки, забезпечуючи її стабільність, трансмісію генів від бактерії до бактерії, впливає на бактеріальну адгезію та агрегацію мікроорганізмів, а також хелатує катіони (магній), зменшує можливість проникнення протимікробних речовин, що, відповідно, підвищує патогенність мікроорганізмів та їх стійкість до АБ. Таким чином, позаклітинна ДНК біоплівок створює локальне катіонно-обмежене середовище та призводить до індукції генів модифікації ліпополісахаридів і, відповідно, забезпечує резистентність до протимікробних препаратів $[5,6]$.

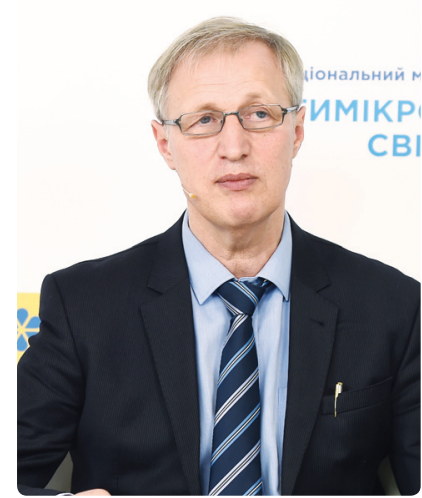

Микола Хайтович, професор, доктор медичних наук, у своїй доповіді висвітлив проблему розвитку інфекцій, асоційованих з наданням медичної допомоги. За словами спікера, резистентність до протимікробних препаратів $\epsilon$ не лише медичною проблемою, яка полягає у збільшенні термінів госпіталізації, лікування та підвищенні рівня летальності, а й економічною та соціальною, що пов'язано із застосуванням дороговартісних АБ широкого спектру дії і підвищенням захворюваності, непрацездатності та витрат на лікування і реабілітацію пацієнтів. За оцінками експертів, якщо проблема резистентності до проти- 
мікробних препаратів буде поширюватися й надалі та не буде напрацьовано глобальної відповіді на неї, то до 2050 р. прогнози щодо смертності пацієнтів внаслідок інфекційних захворювань, асоційованих саме з відсутністю ефективного антибактеріального лікування, будуть сягати > 10 млн осіб, що перевищить смертність від онкологічних та серцево-судинних захворювань [7].

Інфекції, пов'язані з наданням медичної допомоги, становлять групу внутрішньолікарняних інфекцій, що виникають внаслідок надання медичної допомоги протягом певного часового проміжку під час перебування пацієнта у стаціонарі або після виписки зі стаціонару. Епідеміологічні дані щодо інфекцій, пов'язаних з наданням медичної допомоги, свідчать, що вони вражають близько $15 \%$ всіх госпіталізованих пацієнтів, і найбільш поширеними групами інфекційних захворювань $\epsilon$ : інфекції сечових шляхів (36\%), інфекції хірургічного поля (20\%), пневмонія (11-25,3\%) та сепсис (11\%) [8]. Відповідно, ключовими стратегіями боротьби з резистентністю до протимікробних препаратів $\epsilon$ в першу чергу удосконалення системи інфекційного контролю, раціональне призначення АБ та посилення безпеки медичної допомоги.

У своїй доповіді Марина Кривцова, кандидат біологічних наук, доцент, мікробіолог, приділила значну увагу проблемі резистентності до протимікробних препаратів з погляду біоплівкотвірних умовнопатогенних мікроорганізмів. Сьогодні розвиток резистентності до протимікробних лікарських засобів має стрімкий та неконтрольований характер, що пов'язано з такими соціально-економічними причинами, як нераціональне застосування АБ, їх безрецептурний продаж та використання антибактеріальних препаратів у харчовій промисловості, агроіндустрії та ветеринарії. I хоча з моменту створення першого АБ пеніциліну Олександром Флемінгом у 1928 р. не минуло і 100 років, людство фактично знову опинилося у доантибактеріальній ері, що пов'язано з набуттям мікроорганізмами стійкості до лікарських засобів, тобто резистентності. Однією з причин цього $\epsilon$ формування бактеріальної біоплівки, що спричиняє хронізацію та ускладнення перебігу інфекційного процесу та пов'язане з високим рівнем резистентності бактерій у біоплівковій формі до факторів довкілля (температура, рН тощо) та до АБ.

Підвищена резистентність бактерій у біоплівці пов'язана з:

- уповільненням/нездатністю АБ проникати через компоненти полісахаридного матриксу біоплівки;

- зв'язуванням та інактивацією АБ полімерами або ферментами матриксу;

- повільним зв'язуванням АБ з бактеріальними клітинами;

- існуванням клітин-персистерів, які характеризуються сповільненою швидкістю поділу і росту у складі біоплівок.

\section{Практика протистояння резистентності до протимікробних препаратів}

Третю частину конгресу розпочала Лариса Матюха, доктор медичних наук, професор, президент Української асоціації сімейної медицини, яка виступила з доповіддю «Застосування антибіотикотерапії на первинній ланці». Ця тема $\epsilon$ особливо актуальною в умовах пандемії COVID-19, оскільки значна частина пацієнтів, інфікованих SARS-CoV-2, отримують лікування саме на первинній ланці медичної допомоги. І, відповідно до сучасних рекомендацій, під час менеджменту пацієнтів із COVID-19 антибіотикотерапія показана лише хворим із супутньою бактеріальною інфекцією (бактеріальна пневмонія, сепсис, септичний шок, інфекція сечовивідних шляхів та ін.), ризик якої, звичайно, значно підвищується у разі перебування пацієнта в стаціонарі та палаті інтенсивної терапії. Однак, на жаль, сучасні дані свідчать, що більшість клініцистів не дотримуються гайдлайнів та призначають пацієнтам цієї групи АБ. Так, результати попередніх досліджень демонструють, що близько 75\% пацієнтів з COVID-19 емпірично отримують антибіотикотерапію, що в майбутньому загрожуватиме розвитком та блискавичним поширенням резистентності до протимікробних препаратів [9]. Далі спікер детально розповіла про пацієнтів групи ризику тяжкого перебігу COVID-19, зокрема хворих із коморбідною патологією.

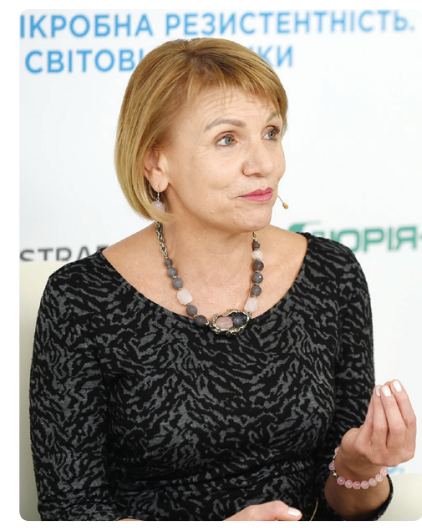

Тетяна Татарчук, доктор медичних наук, професор, членкореспондент Національної академії медичних наук України, заступник директора ДУ «Інститут педіатрії, акушерства і гінекології імені академіка О.М. Лук'янової НАМН України», президент Всеукраїнської громадської організації «Асоціація гінекологів-ендокринологів України», виступила з доповіддю «Раціональна антибіотикотерапія в лікуванні інфекційно-запальних процесів репродуктивної системи жінки». Проблема запальних захворювань в збереженні репродуктивного здоров'я жінок $\epsilon$ дуже важливою. Так, сучасні дані свідчать, що запальні хвороби вульвовагінальної системи та внутрішніх статевих органів $\epsilon$ найпоширенішими станами, з якими жінки звертаються за медичною допомогою. Крім того, проблема запальних захворювань пов'язана з тим фактом, що ці стани в майбутньому асоціюються з розвитком не лише гінекологічної патології (зокрема хронічного больового синдрому, позаматкової вагітності та безпліддя), а й пов'язана з більш високим ризиком розвитку інсульту, раку яєчників і психічних розладів [10]. Тому призначення відповідного ефективного та безпечного лікування пацієнткам цієї групи є вкрай важливим.

Сьогодні клініцисти дотримуються стратегій індивідуалізованого лікування на основі даних доказової медицини, які базуються на індивідуальних особливостях кожного пацієнта, а призначена терапія має значну доказову базу ефективності та безпеки. Групи ризику розвитку запальних захворювань вульвовагінальної системи та внутрішніх статевих органів включають молодих жінок віком 15-24 років, оскільки саме у цій віковій групі найчастіше діагностують інфекції, що передаються статевим шляхом. Відповідно до сучасних рекомендацій, основні принципи лікування запальних захворювань органів малого тазу (33ОМТ) полягають у застосуванні антибактеріальної терапії, яка має бути призначена за наявності «мінімальних критеріїв» і відсутності інших причин, які здатні викликати спостережувану клінічну симптоматику. У разі відсутності точних діагностичних критеріїв рекомендованим $\epsilon$ емпіричне застосування АБ широкого спектру дії проти таких збудників, як Neisseria gonorrhoeae, Chlamydia trachomatis, та анаеробних інфекцій (таблиця).

Професор Олексій Нестеренко виступив 3 доповіддю «Раціональна антибактеріальна терапія-2021», в якій приділив увагу стратегії боротьби з резистентністю до протимікробних препаратів. Практика раціональної антибіотикотерапії полягає у призначенні АБ лише за необхідності, з використанням винятково груп препаратів, які $\epsilon$ максимально ефективними у конкретного пацієнта, а також підбір оптимального дозування, тривалості та шляху введення лікарського засобу. Так, раціональний підхід передбачає вибір оптимального АБ для лікування тяжких позалікарняних або внутрішньолікарняних інфекцій з обов'язковим урахуванням їх спектру активності, рівня антибіотикорезистентності, фармакокінетики, фармакодинаміки.

Резистентність до протимікробних препаратів призводить до збільшення термінів лікування пацієнтів та підвищує летальність. Важливо розуміти, що резистентність полягає у нечутливості (стійкість) бактерій (вірусів/грибів) до лікарських засобів, що застосовують для лікування інфекційних захворювань. Статистичні дані за 2020 р. свідчать, що щорічно у світі внаслідок резистентності до протимікробних препаратів помирає >700 тис. осіб і якщо не вирішувати цю проблему, то кількість померлих з кожним роком буде лише зростати, що, відповідно, призведе до руйнівних наслідків й для економіки країн [12]. Стратегії боротьби з надмірним застосуванням АБ спрямовані на управління терапією із забезпеченням того, щоб кожен пацієнт міг отримувати конкретні ліки проти конкретного патогену в конкретно необхідний час. Крім того, важливим компонентом цієї стратегії $€$ своєчасна та чітка діагностика інфекційних захворювань. Це означає, що клініцист повинен усвідомлювати, по-перше, який саме патоген $\epsilon$ причиною інфекційного захворюван- 
Таблиця

Протоколи антибіотикотерапії при 33ОМт [11]

\begin{tabular}{|c|c|}
\hline \multicolumn{2}{|r|}{ Антибіотикотерапія при 330Мт } \\
\hline Лінія терапії & Протокол антибіотикотерапії \\
\hline \multicolumn{2}{|r|}{ Амбулаторна ланка медичної допомоги } \\
\hline 1-ша & $\begin{array}{l}\text { Цефтріаксон } 1 \text { г одноразового (внутрішньом'язово або внутрішньовенно) } \\
\text { + доксициклін } 100 \text { мг } 2 \text { рази на добу та метронідазол } 500 \text { мг } 2 \text { рази на добу } \\
\text { перорально протягом } 10 \text { днів }\end{array}$ \\
\hline 2-га & $\begin{array}{l}\text { Цефтріаксон } 1 \text { г одноразового (внутрішньом'язово або внутрішньовенно) } \\
\text { + офлоксацин } 200 \text { мг } 2 \text { рази на добу та метронідазол } 500 \text { мг } 2 \text { рази на добу } \\
\text { протягом } 10 \text { днів } \\
\text { або } \\
\text { Цефтріаксон } 1 \text { г одноразового (внутрішньом'язово або внутрішньовенно) } \\
\text { + левофлоксацин } 500 \text { мг } 2 \text { рази на добу та метронідазол } 500 \text { мг } 2 \text { рази } \\
\text { на добу протягом } 10 \text { днів } \\
\text { або } \\
\text { Цефтріаксон } 1 \text { г одноразового (внутрішньом'язово або внутрішньовенно) } \\
\text { + моксифлоксацин } 400 \text { мг } 1 \text { раз на добу протягом } 10 \text { днів }\end{array}$ \\
\hline \multicolumn{2}{|r|}{ Стаціонарне лікування } \\
\hline 1-ша & $\begin{array}{l}\text { Цефтріаксон } 1 \text { г одноразового (внутрішньом'язово або внутрішньовенно) } \\
\text { + доксициклін } 100 \text { мг } 2 \text { рази на добу та метронідазол } 500 \text { мг } 2 \text { рази на добу } \\
\text { перорально протягом } 10 \text { днів }\end{array}$ \\
\hline 2-га & $\begin{array}{l}\text { Доксициклін } 100 \text { мг } 2 \text { рази на добу + цефокситин } 100 \text { мг } 4 \text { рази на добу } \\
\text { (внутрішньом'язово або внутрішньовенно або перорально) протягом } 10 \text { днів }\end{array}$ \\
\hline
\end{tabular}

ня, тобто ідентифікація збудника, по-друге, чим найкраще лікувати наявну патологію, виходячи з результатів чутливості цього патогену до АБ, та, по-третє, як це все здійснити в найкоротші терміни.

Принципи раціональної антимікробної терапії полягають у тому, що суттєвим компонентом процесу клінічного прийняття рішення при емпіричному лікуванні інфекцій мають бути показники локального й регіонального рівнів резистентності до протимікробних препаратів. Саме тому постійний локальний мікробіологічний моніторинг внутрішньолікарняної флори лікувальних закладів дозволяє виявити клінічно значущі патогени-збудники, а постійний локальний мікробіологічний моніторинг забезпечує контролювання ступеня чутливості внутрішньолікарняних патогенів до АБ та слугує основним фактором вибору препарату чи їх комбінації для стартової емпіричної деескалаційної антибіотикотерапії. Сучасні дані свідчать, що АБ - одна з найбільш широко застосовуваних та неправильно призначуваних груп лікарських засобів. Практично всі пацієнти, які знаходяться у критичному стані та отримують лікування у відділеннях інтенсивної терапії різної спеціалізації, на тому чи іншому етапі лікування отримують протимікробні препарати - АБ, противірусні та протигрибкові. І хоча внесок АБ в зниження летальності хворих хірургічного профілю не перевищує 20\%, несвоєчасна, неадекватна клінічній ситуації протимікробна терапія може істотно погіршити прогноз - призвести до достовірного підвищення летальності у 1,5-3 рази.

\section{Підсумки конгресу - \\ резолюція-звернення}

За результатами обговорення проблеми резистентності до протимікробних препаратів під час проведення 1-го Національного медичного конгресу з міжнародною участю «Протимікробна резистентність. Світові виклики», Всеукраїнське лікарське товариство разом із співорганізаторами заходу - Національною лікарською радою України, Українською медичною експертною спільнотою, Асоціацією стоматологів України, Українська асоціація сімейної медицини та понад 3500 учасників - вирішили звернутися з проєктом резолюції до Президента України, Ради Національної безпеки та оборони України, КМУ щодо необхідності забезпечення:

- аналізу та контролю за виконанням розпорядження КМУ від 06.03.2019 р. № 116-р «Про затвердження Національного плану дій щодо боротьби із стійкістю до протимікробних препаратів»;

- приєднання України до GLASS;

- розробки та впровадження загальнонаціональної системи контролю за застосуванням АБ у клінічній практиці;
- висвітлення питань актуальності загрози поширення сепсису та виявлення септицемії як складової моніторингу резистентності до протимікробних препаратів, запровадження сучасних стандартів щодо мікробіологічної діагностики крові й інших в нормі стерильних рідин організму у всіх лікувальнопрофілактичних закладах, які надають стаціонарну допомогу;

- сприяння розробці та поширенню типових рішень, запровадженню локальних формулярів/інструкцій щодо порядку проведення антибіотикопрофілактики та антибактеріальної терапії в підрозділах лікувально-профілактичних закладів на підставі локальних даних моніторингу резистентності;

- імплементації гайдлайнів Європейської комісії 3 питань визначення чутливості до АБ (European Committee on Antimicrobial Susceptibility Testing - EUCAST) як настанов прямої дії для мікробіологічних лабораторій всіх лікувальнопрофілактичних закладів;

- запровадження єдиної системи центрів моніторингу резистентності до протимікробних препаратів (за аналогією до GLASS);

- створення національної референс-лабораторії з дослідження чутливості до АБ;

- розробки національних настанов щодо управління резистентністю до протимікробних препаратів;

- відновлення епідеміологічної частини (структури) санітарно-епідеміологічної служби;

- відновлення додипломної і післядипломної підготовки фахівців-епідеміологів і лікарів профілактичної медицини;

- виділення на подальші роки коштів з Державного бюджету на наукові дослідження резистентності до протимікробних препаратів в Національній академії медичних наук та Національній академії аграрних наук України з метою їх впровадження в медицину, ветеринарію та захист довкілля задля зменшення як самої резистентності до протимікробних препаратів, так і її наслідків [13].

\section{Список використаної літератури/References:}

1. World Health Organization (2001) Anti-Infective Drug Resistance Surveillance and Containment Team (2001). WHO global strategy for containment of antimicrobial resistance (https:// apps.who.int/iris/handle/10665/66860).

2. WHO (2015) Global Action Plan on Antimicrobial Resistance (https://www.who.int/antimicrobial-resistance/publications/global-action-plan/en/).

3. Nishihara T., Koseki T. (2000) Microbial etiology of periodontitis. Periodontol., 36: 14-26. doi: 10.1111/j.1600-0757.2004.03671.x.

4. Rostami N., Shields R.C., Yassin S.A. et al. (2017) A Critical Role for Extracellular DNA in Dental Plaque Formation. J. Dent. Res., 96(2): 208-216. doi: 10.1177/0022034516675849.

5. Mulcahy H., Charron-Mazenod L., Lewenza S. et al. (2008) Extracellular DNA chelates cations and induces antibiotic resistance in Pseudomonas aeruginosa biofilms. PLoS Pathog., 4(11): e1000213. doi: 10.1371/journal.ppat.1000213.

6. Hirschfeld J. (2014) Dynamic interactions of neutrophils and biofilms. J. Oral. Microbiol., 6: 26102. doi: 10.3402/jom.v6.26102.

7. de Kraker M.E.A., Stewardson A.J., Harbarth S. et al. (2016) Will 10 Million People Die a Year due to Antimicrobial Resistance by 2050? PLoS Med., 13(11): e1002184. doi: 10.1371/journal. pmed.1002184.

8. Khan H.A., Baig F.K., Mehboob R. (2017) Nosocomial infections: Epidemiology, prevention, control and surveillance. Asian Pacific J. Trop. Biomed., 7(5): 478-482.

9. Sieswerda E., de Boer M.G.J., Bonten M.M.J. et al. (2021) Recommendations for antibacterial therapy in adults with COVID-19 — an evidence based guideline. Clin. Microb. Inf., 27(1): 61-66. https://doi.org/10.1016/j.cmi.2020.09.041.

10. Tough DeSapri K.A., Christmas M.M., Karjane N.W. et al. (2019) Pelvic Inflammatory Disease. Medscape, May 3.

11. Brun J-L., Castan B., Barbeyrac B. et al. (2020) Jean-LucBrunaBernardCastanbBertillede Barbeyrac. J. Gynecol. Obstet. Human Reproduct., 49(5): 101714. https://doi.org/10.1016/j. jogoh.2020.101714.

12. AMR Industry Allianc (2020) 2020 progress report (https://www.amrindustryalliance.org/ wp-content/uploads/2020/01/AMR-2020-Progress-Report.pdf).

13. Ukrainian Medical Association (2021) Resolution of the First National Medical Congress with international participation «Antimicrobial resistance. World Challenges» (https://umv.com. ua/rezolyuciya-i-nacionalnogo-medichnogo-kongresu-z-mizhnarodnoyu-uchastyu-protimikrobna-rezistentnist-svitovi-vikliki/) (In Ukr.). 